\title{
Effect of a synthetic inhibitor of urokinase plasminogen activator on the migration and invasion of human cervical cancer cells in vitro
}

\author{
XUECHUN WANG $^{1 *}$, ZHONGQING JIANG $^{2 *}$, JIAN AN $^{1}$, XIAODAN MAO $^{1}$, FEN LIN $^{1}$ and PENGMING SUN ${ }^{1}$ \\ ${ }^{1}$ Laboratory of Gynecologic Oncology, Fujian Provincial Maternity and Children Hospital, \\ Affiliated Hospital of Fujian Medical University, Fuzhou, Fujian 350001; ${ }^{2}$ Department of Gynecology, \\ Xiamen Hospital of Traditional Chinese Medicine, Xiamen, Fujian 361009, P.R. China
}

Received July 2, 2017; Accepted November 16, 2017

DOI: $10.3892 / \mathrm{mmr} .2018 .8414$

\begin{abstract}
As a notable feature of malignant tumors, invasion and metastasis are important events in the process of tumor progression. Amiloride, a synthetic inhibitor of urokinase plasminogen activator (uPA), is involved in these events. To evaluate the therapeutic value of amiloride in cervical cancer, HeLa cells were used as in vitro cellular models. The migration and invasion abilities of HeLa cells, in addition to the mRNA expression of matriptase, uPA, uPA receptor and $72 \mathrm{kDa}$ type IV collagenase (MMP-2), were detected using scratch assays, Transwell chamber assays and reverse transcription-quantitative polymerase chain reaction (RT-qPCR). The results of RT-qPCR demonstrated that the mRNA expression of UPA and MMP-2 in HeLa cells was downregulated significantly in a dose-dependent manner when incubated with various concentrations of amiloride for $24 \mathrm{~h}$. The migration distance of HeLa cells was significantly shorter at 6, 12 and $24 \mathrm{~h}$ following incubation with amiloride $(\mathrm{P}<0.01)$, and there was a positive correlation between cell migratory ability and cellular uPA protein expression level $(r=0.955, \mathrm{P}<0.01)$. The number of HeLa cells that penetrated the Matrigel following incubation for $24 \mathrm{~h}$ with different concentrations of amiloride decreased significantly compared with the control group, indicating that cell invasiveness was positively correlated with the protein expression level of uPA in the cells $(r=0.993$, $\mathrm{P}<0.01)$. The present study demonstrated that amiloride was able to specifically inhibit the mRNA expression levels of
\end{abstract}

Correspondence to: Professor Pengming Sun, Laboratory of Gynecologic Oncology, Fujian Provincial Maternity and Children Hospital, Affiliated Hospital of Fujian Medical University, 18 Daoshan Road, Fuzhou, Fujian 350001, P.R. China

E-mail: fmsun1975@fjmu.edu.cn

*Contributed equally

Key words: amiloride, cervical cancer, urokinase-type plasminogen activator, invasion, metastasis
uPA in HeLa cells, and sequentially downregulate the mRNA expression of downstream MMP-2 in the uPA system, thereby suppressing the migratory and invasive ability of HeLa cells. Therefore, amiloride may be a promising therapeutic target for the treatment of cervical cancer.

\section{Introduction}

Cervical cancer is the third most common cancer in women worldwide $(1,2)$, and $>85 \%$ of the cervical cancer burden is in developing countries $(2,3)$. Metastasis is one of the primary causes of treatment failure and mortality in women diagnosed with cervical cancer, indicating that the inhibition of metastasis serves a pivotal role in improving the survival and cure rate.

Accumulating studies have reported the association between serine proteases, and tumor invasion and metastasis. Urokinase plasminogen activator (uPA) is an important serine protease (4), which serves a role in the extracellular matrix degradation process, in addition to being associated with cell division, adhesion and migration. uPA receptor (uPAR) is a high affinity receptor for uPA on the cell surface (5), and may activate uPA and localize to the cell surface to provide a local concentration mechanism between cells and the junction of the cell and matrix, thus creating a suitable environment for uPA-mediated proteolysis in UPAR-expressing tumor cells (6). The level of expression of UPA and UPAR in invasive cervical cancer tissues is increased compared with normal cervical tissues (7). The same phenomenon may be observed with matriptase, a newly-identified type II serine transmembrane protease, and $72 \mathrm{kDa}$ type IV collagenase (MMP-2), a subtype of the matrix metalloproteinase (MMP) family (8-11). Additionally, matriptase is able to hydrolyze single-stranded pro-uPA to form an active double-stranded structure. Activated uPA converts plasminogen into plasmin, which in turn converts pro-MMPase to MMPs (including MMP-2), resulting in proteolysis of the extracellular matrix. Subsequently, a cascade of protein cleavage reactions occurs, promoting tumor growth and angiogenesis, in addition to accelerating extracellular matrix degradation (12). Thus, inhibition of tumor invasion and metastasis via suppression of the uPA system in tumor cells has become the focus of studies. 
The mechanism underlying the invasion and metastasis induced by overexpression of matriptase, uPA, uPAR and MMP-2 in cervical cancer remains to be elucidated. Additionally, the intricate network of the uPA system remains unclear, and has become a leading area of research and development in cervical cancer. Amiloride, as a synthetic inhibitor of uPA, serves a role in tumor invasion and metastasis prevention by inhibiting the proteolytic catalytic activity of the extracellular area of uPA, in a competitive and selective manner $(13,14)$. The purpose of the present study was to investigate the effects of amiloride on the invasion and metastasis of human cervical cancer cells in vitro.

\section{Materials and methods}

Cell culture. The human cervical cancer cell line HeLa was obtained from the Laboratory of Gynecologic Oncology of Fujian Provincial Maternity and Children Hospital, Affiliated Hospital of Fujian Medical University (Fujian, China). All cells were cultured in 90\% Dulbecco's modified Eagle's medium (DMEM; Gibco; Thermo Fisher Scientific, Inc., Waltham, MA, USA) supplemented with $10 \%$ fetal bovine serum (Gibco; Thermo Fisher Scientific, Inc.), $1 \%$ penicillin, and $1 \%$ streptomycin $(100 \mathrm{IU} / \mathrm{ml})$ in a $37^{\circ} \mathrm{C}$ incubator with $5 \% \mathrm{CO}_{2}$.

Drug treatment. The amiloride was purchased from Sigma-Aldrich; Merck KGaA (Darmstadt, Germany) and prepared in $100 \%$ dimethyl sulfoxide (DMSO). Prior to treatment, the HeLa cervical cancer cells were seeded in 6-well plates at a density of $1 \times 10^{7}$ cells/well and cultured in $3 \mathrm{ml}$ serum-free DMEM for $12 \mathrm{~h}$ to achieve adherence. For the dose-dependent study, five groups were set up; four groups were treated with final concentrations of 50,100, 150 or $200 \mu \mathrm{mol} / \mathrm{l}$ amiloride, respectively, for $24 \mathrm{~h}$, and one group treated only with DMSO was used as a control. For the time-dependent study, cells were cultured with $150 \mu \mathrm{mol} / 1$ amiloride for different time periods $(2,4$ or $8 \mathrm{~h})$. Similarly, prior to the cellular scratch assay and Transwell chamber assay, cells were incubated with final concentrations of 50,100 or $150 \mu \mathrm{mol} / 1$ amiloride for $24 \mathrm{~h}$, or incubated with $150 \mu \mathrm{mol} / 1$ amiloride for different time periods $(6,12$ or $24 \mathrm{~h})$.

Detection of mRNA expression levels of matriptase, $u P A$, $U P A R$ and MMP-2 by reverse transcription-quantitative polymerase chain reaction ( $R T-q P C R)$. Total RNA was extracted using TRIzol reagent (Invitrogen; Thermo Fisher Scientific, Inc.). Samples of $1 \mu \mathrm{g}$ DNase I-treated RNA were reverse-transcribed to cDNA using the reverse transcription system A3500 (Promega Corporation, Madison, WI, USA). The PCR primer sets were synthesized by Takara Biotechnology Co., Ltd. (Dalian, China) and were as follows: GAPDH sense, 5'-GAA GGTGAAGGTCGGAGTC-3' and antisense, 5'-GAAGAT GGTGATGGGATTTC-3'; matriptase sense, 5'-GGGACA CACCCAGTATGGAGG-3' and antisense, 5'-CCGGAATCA CCCTGGCAGGA-3'; uPA sense, 5'-AGAATTCACCACCAT CGAGA-3' and antisense, 5'-ATCAGCTTCAACAGTCAT-3'; uPAR sense, 5'-GAGCTGGTGGAGAAAAGCTG-3' and antisense, 5'-TGTTGCAGCATTTCAGGAAG-3'; and MMP-2 sense, 5'-AGATCTTCTTCTTCAAGGAGACCGGTT-3' and antisense, 5'-GGCTGGTCAGTGGCTTGGGGTA-3'. The thermocycling conditions of qPCR were as follows: $95^{\circ} \mathrm{C}$ for $15 \mathrm{sec}, 45$ cycles of denaturation at $95^{\circ} \mathrm{C}$ for $5 \mathrm{sec}$, annealing at $60^{\circ} \mathrm{C}$ for $20 \mathrm{sec}, 95^{\circ} \mathrm{C}$ for $1 \mathrm{~min}$ and then cooled to $55^{\circ} \mathrm{C}$. The relative levels of matriptase, uPA, uPAR and MMP-2 mRNA was quantified using the $2^{-\Delta \Delta C q}$ method (15) and normalized to GAPDH expression. Following qPCR analysis, the PCR products were also electrophoresed on $2 \%$ agarose gel stained with ethidium bromide.

ELISA analysis for UPA and MMP-2 quantification. The protein expression quantification for uPA and MMP-2 was performed using human uPA and MMP-2 ELISA kits (cat. nos. SEA140Hu and SEA100Hu; Cloud-Clone Corp., Wuhan, China), according to the manufacturer's instructions. Supernatant obtained from the cell culture with different concentrations of amiloride $(0,50,100,150$ or $200 \mu \mathrm{mol} / \mathrm{l})$, or different treatment durations $(0,2,4$ or $8 \mathrm{~h})$, were harvested and centrifuged at $12,000 \mathrm{xg}$ at $4^{\circ} \mathrm{C}$ for $10 \mathrm{~min}$. The results of the reaction were measured at $450 \mathrm{~nm}$, using an automated microplate spectrophotometer (RT-6100; Rayto Life and Analytical Sciences Co., Ltd., Shenzhen, China). Total protein was quantified in $\mathrm{pg} / \mathrm{ml}$. The results were calculated using the standard curves created in each assay. The ELISAs were performed in a blinded manner and in triplicate.

Cellular scratch assay. The horizontal migration of cells was assessed via a scratch assay (16). Cells were seeded at a density of $5.0 \times 10^{5}$ cells/well and observed with an inverted microscope at $0,6,12$ and $24 \mathrm{~h}$ post-scratch. Image ProExpress C software 5.1 (Olympus Corporation, Tokyo, Japan) was used to measure the alteration in cell distance between the scratches. The average horizontal migration distance was calculated using the following formula: $\mathrm{Width}_{0 \mathrm{~h}}-\mathrm{Width}_{\text {post-scratching }}$.

Transwell chamber assay. The cellular invasive capacity was determined using a Matrigel invasion chamber assay, as previously reported (17). Cells were seeded at a density of $5.0 \times 10^{5}$ cells/well. The number of cells on the underside of the filter was determined by counting cells in five random fields from three filters for each treatment, at x200 magnification with an inverted microscope (Olympus Corporation).

Statistical analysis. All experiments were performed in triplicate. Statistical analysis was performed using the average results of three repeated experiments under identical conditions. Numerical data are presented as the mean \pm standard deviation. A one-way analysis of variance was performed for multiple comparisons of groups, which was followed by the Fisher's least significant difference post hoc test, and associated parameters were further analyzed using the Pearson's correlation test. Data were analyzed using SPSS software 19.0 for Windows (SPSS Inc., Chicago, IL, USA). $\mathrm{P}<0.05$ was considered to indicate a statistically significant difference.

\section{Results}

Dose-dependent mRNA expression of uPA, MMP-2, matriptase and UPAR following treatment with amiloride. 
A

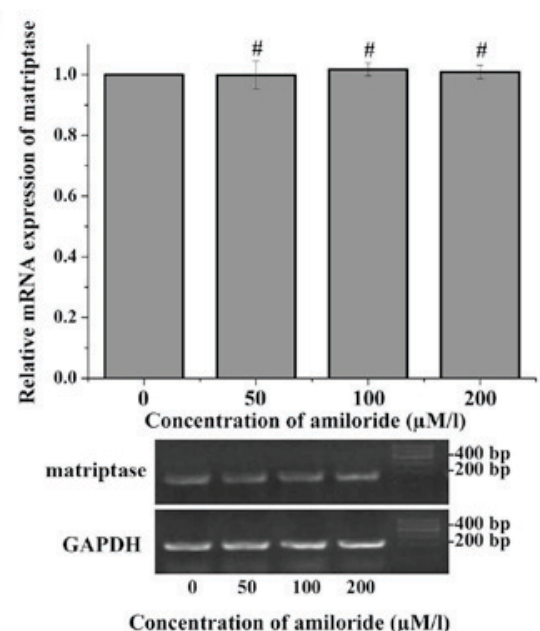

C

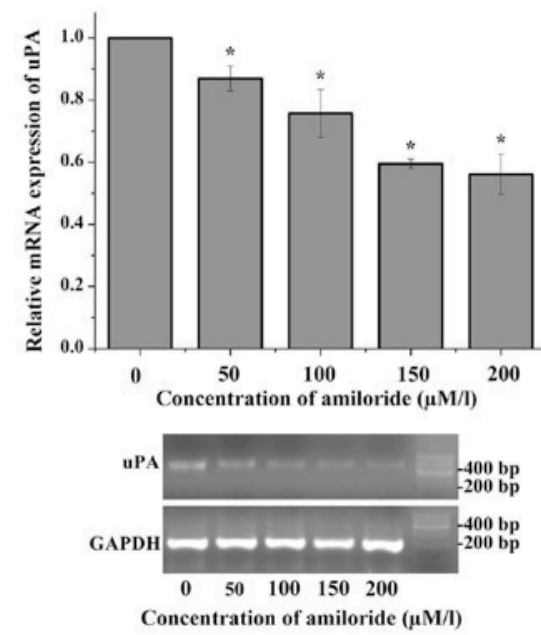

B

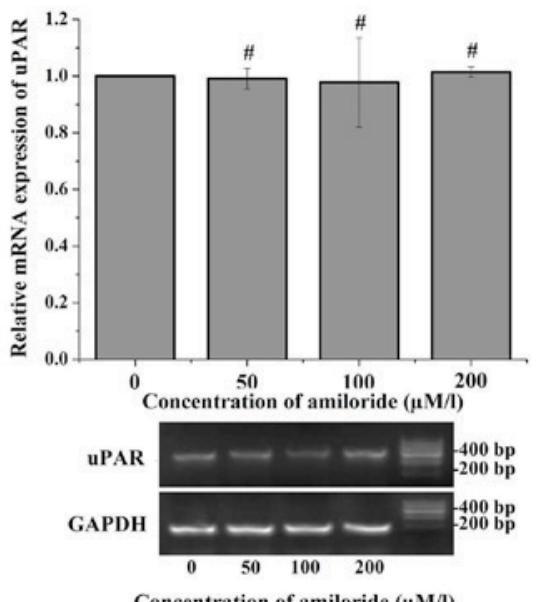

D

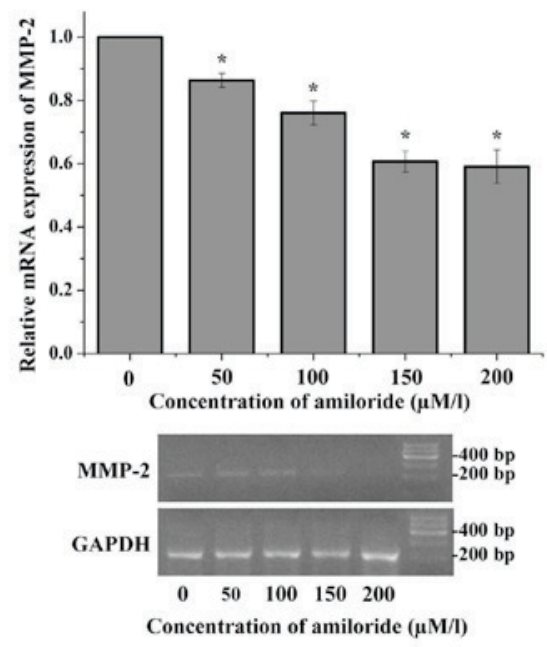

Figure 1. Expression of matriptase, uPA, uPAR and MMP-2 mRNA in HeLa cells treated with amiloride. The relative mRNA expression levels of matriptase, uPA, uPAR and MMP-2 were detected in HeLa cells treated with different concentrations of amiloride using RT-qPCR. The images of the gels are representative of the electrophoresed RT-qPCR products on $2 \%$ agarose gel stained with ethidium bromide. The $0 \mu$ mol/l concentration of amiloride group was set as the negative control. (A) No statistically significant differences were observed between the mRNA expression levels of matriptase in HeLa cells cultured with various concentrations of amiloride. (B) No statistically significant differences were observed between the mRNA expression levels of uPAR in HeLa cells cultured with various concentrations of amiloride. (C) Amiloride significantly inhibited the mRNA expression level of uPA in HeLa cells in a concentration-dependent manner, and there was no significant difference in the levels between the $150 \mu \mathrm{mol} / 1$ group and the $200 \mu \mathrm{mol} / 1$ group. (D) Amiloride significantly inhibited the mRNA expression level of MMP-2 in HeLa cells in a concentration-dependent manner, and there was no significant difference in the levels between the $150 \mu \mathrm{mol} / 1$ group and the $200 \mu \mathrm{mol} / 1$ group. ${ }^{*} \mathrm{P}<0.05,{ }^{*} \mathrm{P}>0.05 \mathrm{vs} .0 \mu \mathrm{mol} / 1$ group. RT-qPCR, reverse transcription-quantitative polymerase chain reaction; uPA, urokinase plasminogen activator; uPAR, urokinase plasminogen activator receptor; MMP-2, $72 \mathrm{kDa}$ type IV collagenase.

Following incubation with various concentrations of amiloride (50, 100 and $200 \mu \mathrm{mol} / \mathrm{l})$ for $24 \mathrm{~h}$, there were no significant differences in matriptase mRNA expression between in HeLa cells treated with different concentrations of amiloride and the control group. A similar result was observed with the mRNA expression of UPAR in the HeLa cells following treatment with amiloride (matriptase, $\mathrm{F}=0.282, \mathrm{P}=0.837$; uPAR, $\mathrm{F}=0.106$, $\mathrm{P}=0.954$; Fig. 1A and B). However, following incubation with different concentrations of amiloride $(50,100,150$ and $200 \mu \mathrm{mol} / \mathrm{l}$ ) for $24 \mathrm{~h}$, the mRNA expression levels of uPA and MMP-2 were significantly downregulated compared with the control group (uPA, F=42.639, $\mathrm{P}<0.01$; MMP-2, $\mathrm{F}=77.357$, $\mathrm{P}<0.01)$. With the concentration of amiloride increasing, the mRNA expression levels of uPA and MMP-2 exhibited a gradual steady decrease. However, there was no significant difference between the $150 \mu \mathrm{mol} / 1$ group and the $200 \mu \mathrm{mol} / 1$ group (uPA, $\mathrm{P}=0.413$; MMP-2, $\mathrm{P}=0.588$; Fig. $1 \mathrm{C}$ and D).
Time-dependent mRNA expression of UPA, MMP-2, matriptase and UPAR following treatment with amiloride. The expression of UPA and MMP-2 was adjusted by amiloride in a dose-dependent manner, which was not observed with the expression of matriptase and UPAR. A time-dependent study was additionally performed to analyze the mRNA expression of UPA and MMP-2 following treatment with amiloride. Compared with the control group, the mRNA expression levels of uPA in HeLa cells treated with $150 \mu \mathrm{mol} / \mathrm{l}$ amiloride exhibited a significant time-dependent decrease following incubation for $2-8 \mathrm{~h}(\mathrm{~F}=21.042, \mathrm{P}<0.01$; Fig. 2A). Notably, in the first $2 \mathrm{~h}$ of treatment, the mRNA expression of MMP-2 was not observed to be significantly different between the cells treated with $150 \mu \mathrm{mol} / 1$ amiloride and the control cells $(\mathrm{P}=0.958)$. A total of $4 \mathrm{~h}$ following the start of treatment, a decrease in MMP-2 mRNA expression was observed in the HeLa cells, which was dependent on the incubation time compared with 
A

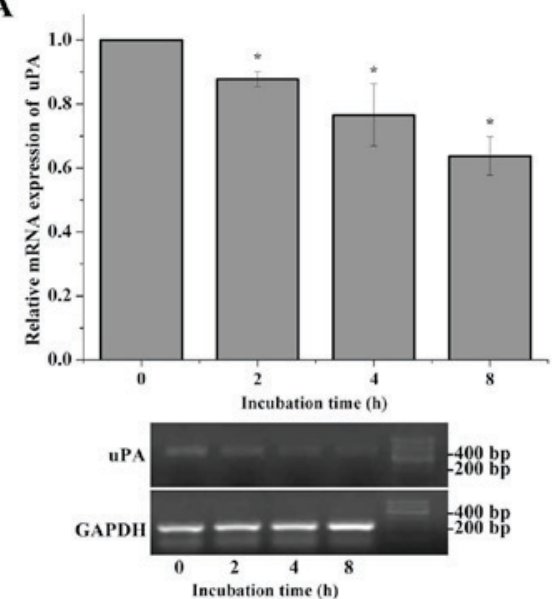

B

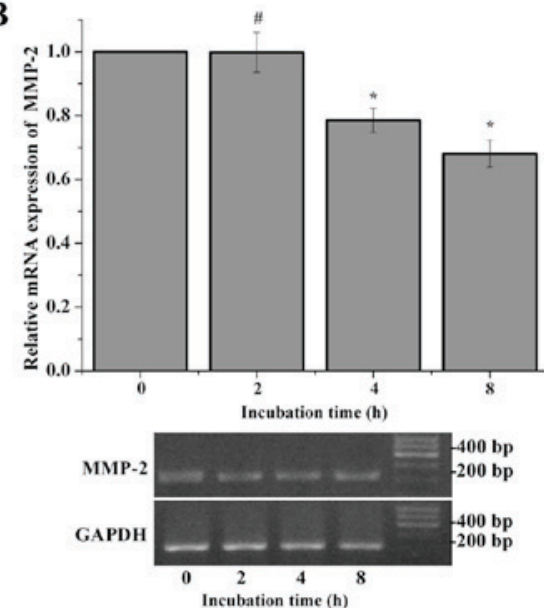

Figure 2. Relative mRNA levels of uPA and MMP-2 in HeLa cells treated with $150 \mu$ mol/l amiloride for different durations were determined via RT-qPCR analysis. The images of the gels are representative of the electrophoresed RT-qPCR products on $2 \%$ agarose gel stained with ethidium bromide. The $0 \mathrm{~h}$ incubation time was set as the negative control. (A) With a prolonged incubation time, the mRNA expression level of uPA decreased. (B) The mRNA expression level of MMP-2 in HeLa cells following culturing in $150 \mu \mathrm{mol} / 1$ amiloride for $2 \mathrm{~h}$ was not reduced compared with the control group, whereas the mRNA expression level of MMP-2 in the intervention groups cultured for 4 and $8 \mathrm{~h}$ was significantly reduced compared with the control group. ${ }^{*} \mathrm{P}<0.01,{ }^{*} \mathrm{P}>0.05$ vs. $0 \mathrm{~h}$ group. RT-qPCR, reverse transcription-quantitative polymerase chain reaction; uPA, urokinase plasminogen activator; MMP-2, $72 \mathrm{kDa}$ type IV collagenase.

A

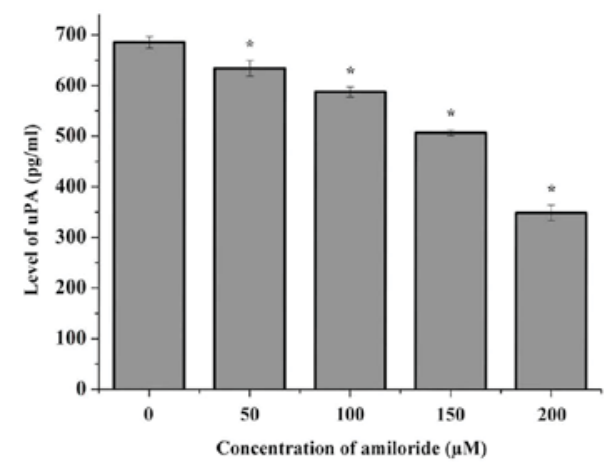

C

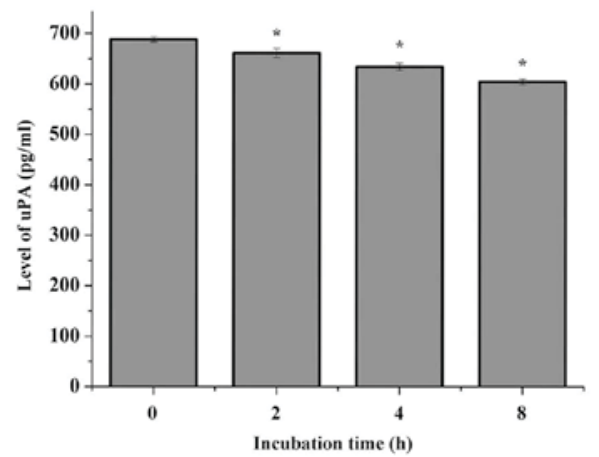

B

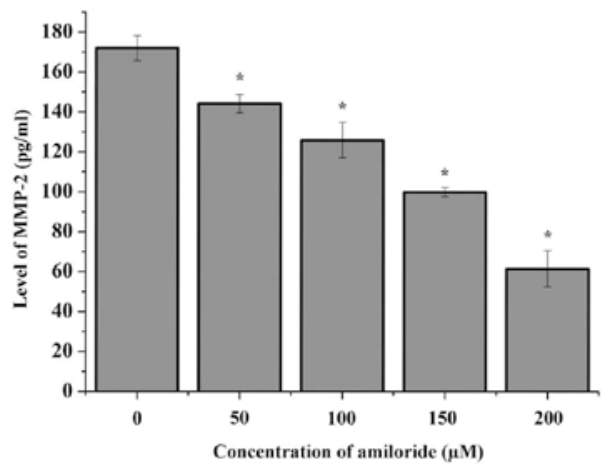

D

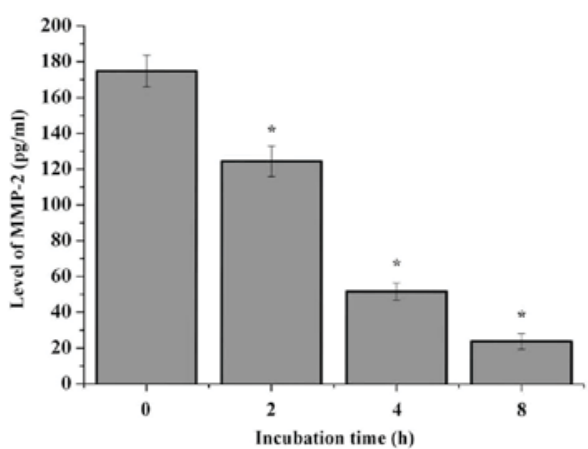

Figure 3. Protein expression of uPA and MMP-2 following treatment with amiloride. The protein expression levels of (A) uPA and (B) MMP-2 in HeLa cells treated with different concentrations of amiloride, and of (C) UPA and (D) MMP-2 across different time periods, were detected by quantitative ELISA. With increasing amiloride concentration and treatment duration, the protein expression of uPA and MMP-2 decreased. ${ }^{*} \mathrm{P}<0.05$ vs. respective control. uPA, urokinase plasminogen activator; MMP-2, $72 \mathrm{kDa}$ type IV collagenase.

the control group ( $\mathrm{F}=42.575, \mathrm{P}<0.01$; Fig. $2 \mathrm{~B})$. These results suggested that amiloride may inhibit the mRNA expression level of UPA and MMP-2 in a time-dependent manner.

Protein expression of $U P A$ and MMP-2 following treatment with amiloride. The protein expression of UPA and MMP-2 in
HeLa cells treated with different concentrations of amiloride was quantitatively detected using ELISA, and the data are presented in Fig. 3. The results indicated a decrease in uPA and MMP-2 mRNA in the cells following treatment with 50,100 or $200 \mu \mathrm{mol} / 1$ amiloride, when compared with the control group $(\mathrm{P}<0.05$; Fig. $3 \mathrm{~A}$ and $\mathrm{B})$. Similarly, the protein 
A
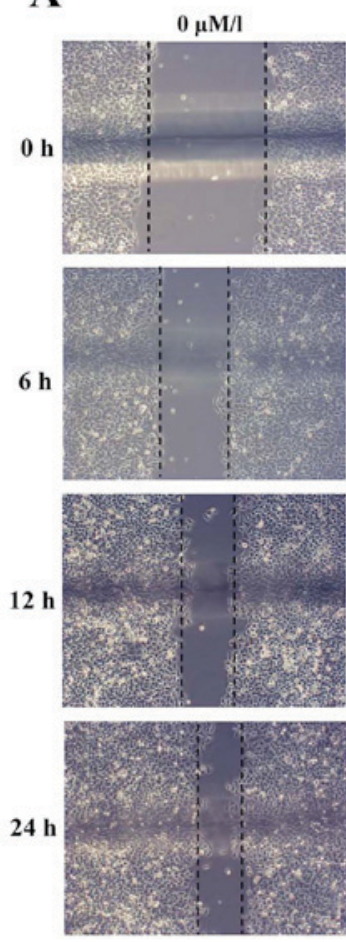

B

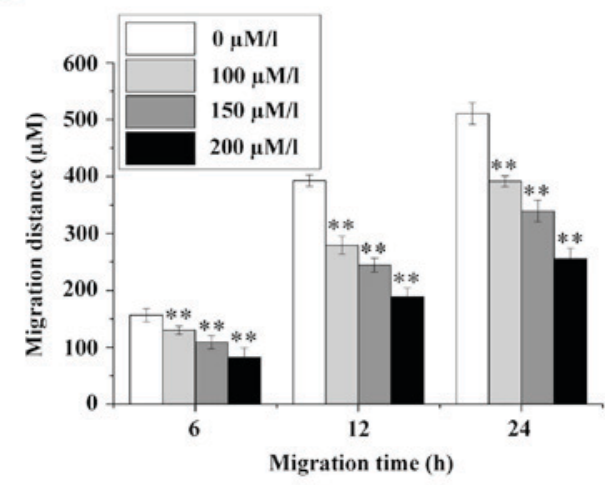

$50 \mu \mathrm{M} / 1$
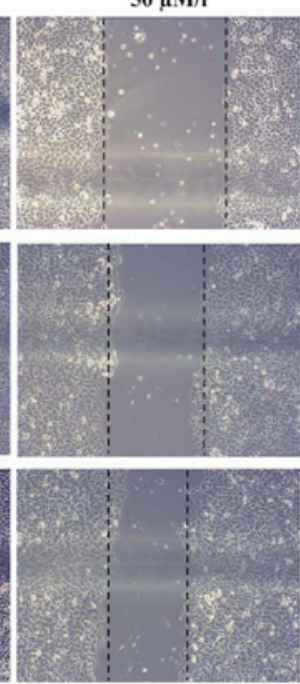

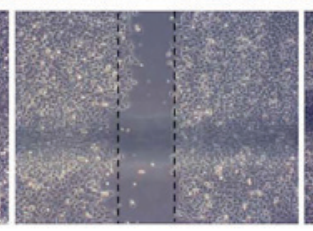

C
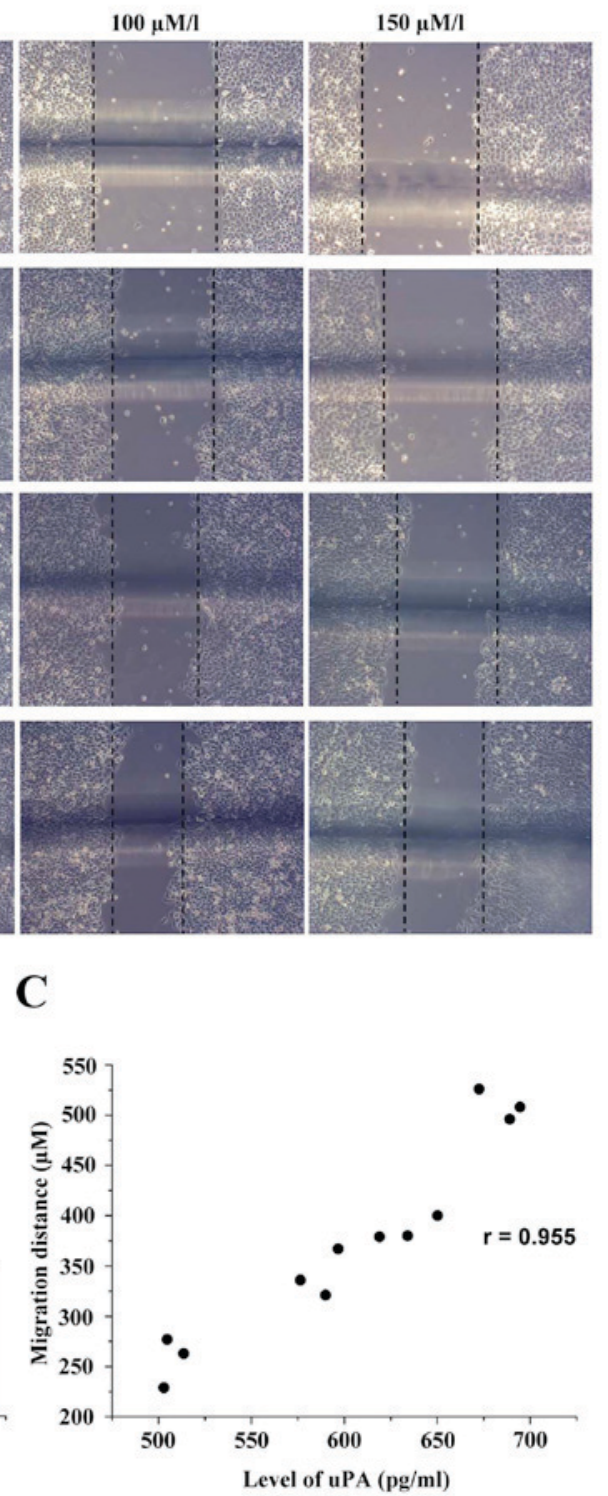

Figure 4. Migration of HeLa cells following treatment with amiloride (magnification, x100). (A) The migration distance of HeLa cells at the time points of 6,12 and $24 \mathrm{~h}$ exhibited a downward trend. As the concentration of amiloride increased, the migration distance decreased. (B) Quantification of migration distance of HeLa cells incubated with different concentration of amiloride at different time-points. (C) Correlation between the migration distance of HeLa cells and different expression levels of uPA. ${ }^{* *} \mathrm{P}<0.01 \mathrm{vs} .0 \mu \mathrm{mol} / 1$. uPA, urokinase plasminogen activator.

expression levels of UPA and MMP-2 in the HeLa cells treated with $150 \mu \mathrm{mol} / 1$ amiloride decreased with the prolonged treatment duration $(0,2,4$ and $8 \mathrm{~h})(\mathrm{P}<0.05$; Fig. $3 \mathrm{C}$ and $\mathrm{D})$.

Effect of amiloride on the migration of HeLa cells. The migration distances of HeLa cells at the time points of 6, 12 and $24 \mathrm{~h}$ were $156.44 \pm 11.35,392.89 \pm 9.93$ and $510.67 \pm 19.05 \mu \mathrm{m}$, respectively, in the control group without amiloride, as determined by cellular scratch assay. When the concentration of amiloride was $50 \mu \mathrm{mol} / 1$, the migration distances of HeLa cells at 6, 12 and $24 \mathrm{~h}$ were $130.11 \pm 7.39,279.33 \pm 15.90$ and $391.78 \pm 9.56 \mu \mathrm{m}$, respectively. When the concentration of amiloride was $100 \mu \mathrm{mol} / 1$, the migration distances of HeLa cells at 6, 12 and $24 \mathrm{~h}$ were $109.11 \pm 11.60,244.56 \pm 12.24$ and $339.78 \pm 18.86 \mu \mathrm{m}$, respectively. When the concentration of amiloride was $150 \mu \mathrm{mol} / 1$, the migration distances of HeLa cells at 6, 12 and $24 \mathrm{~h}$ were $82.00 \pm 17.69,188.78 \pm 15.53$ and $256.00 \pm 18.06 \mu \mathrm{m}$, respectively. All distances in the intervention groups were significantly decrease compared with the control group $(0 \mu \mathrm{mol} / \mathrm{l})(\mathrm{F}=56.893,360.000$ and 360.038 , respectively; $\mathrm{P}<0.01$; Fig. 4A and B). Correlation analysis demonstrated that there was a positive correlation between cell migration distance and the expression level of $\mathrm{uPA}(\mathrm{r}=0.955, \mathrm{P}<0.01$; Fig. 4C).

Effect of amiloride on the invasion of HeLa cells. The HeLa cells were cultured with $0,50,100$ and $150 \mu \mathrm{mol} / 1$ amiloride for $24 \mathrm{~h}$. The results of the cell invasion assay demonstrated that the number of HeLa cells that passed through the membrane was significantly decreased as the amiloride concentration increased: Control group $(0 \mu \mathrm{mol} / 1), 81.00 \pm 1.91$; $50 \mu \mathrm{mol} / 1$ amiloride, $71.67 \pm 2.27 ; 100 \mu \mathrm{mol} / 1$ amiloride, $60.93 \pm 0.31$; and $150 \mu \mathrm{mol} / 1$ amiloride, $47.47 \pm 1.45$. There was a negative association between the number of cells penetrating 
A
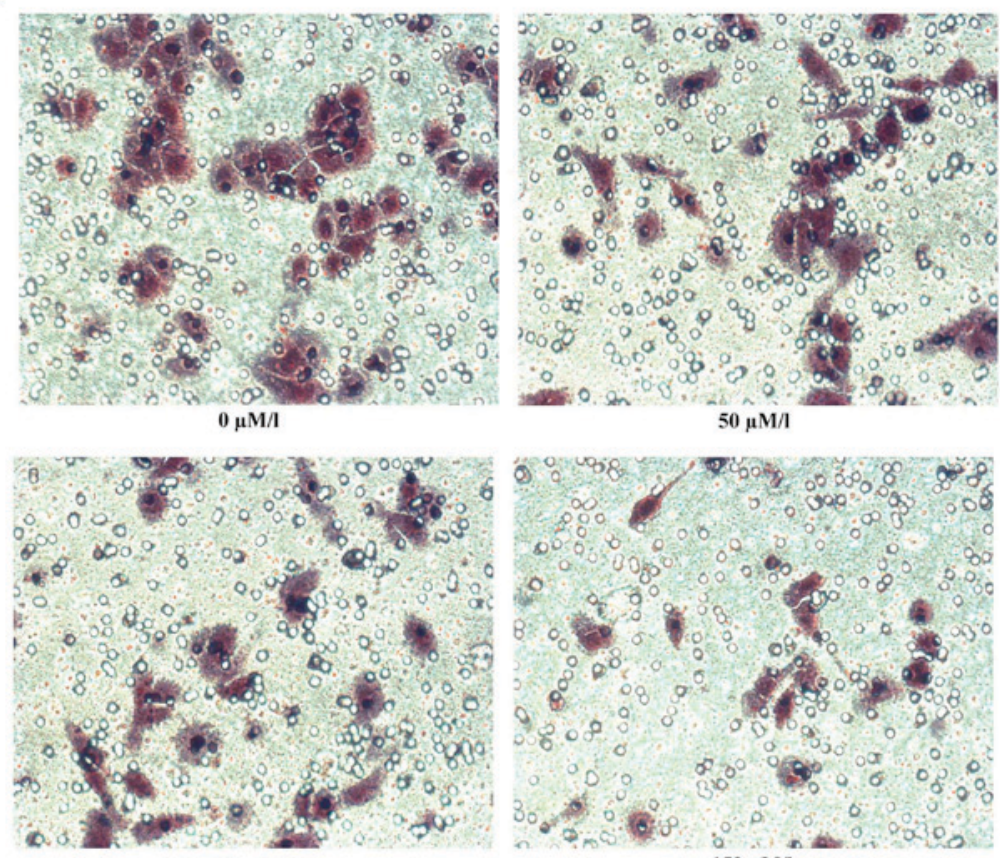

B
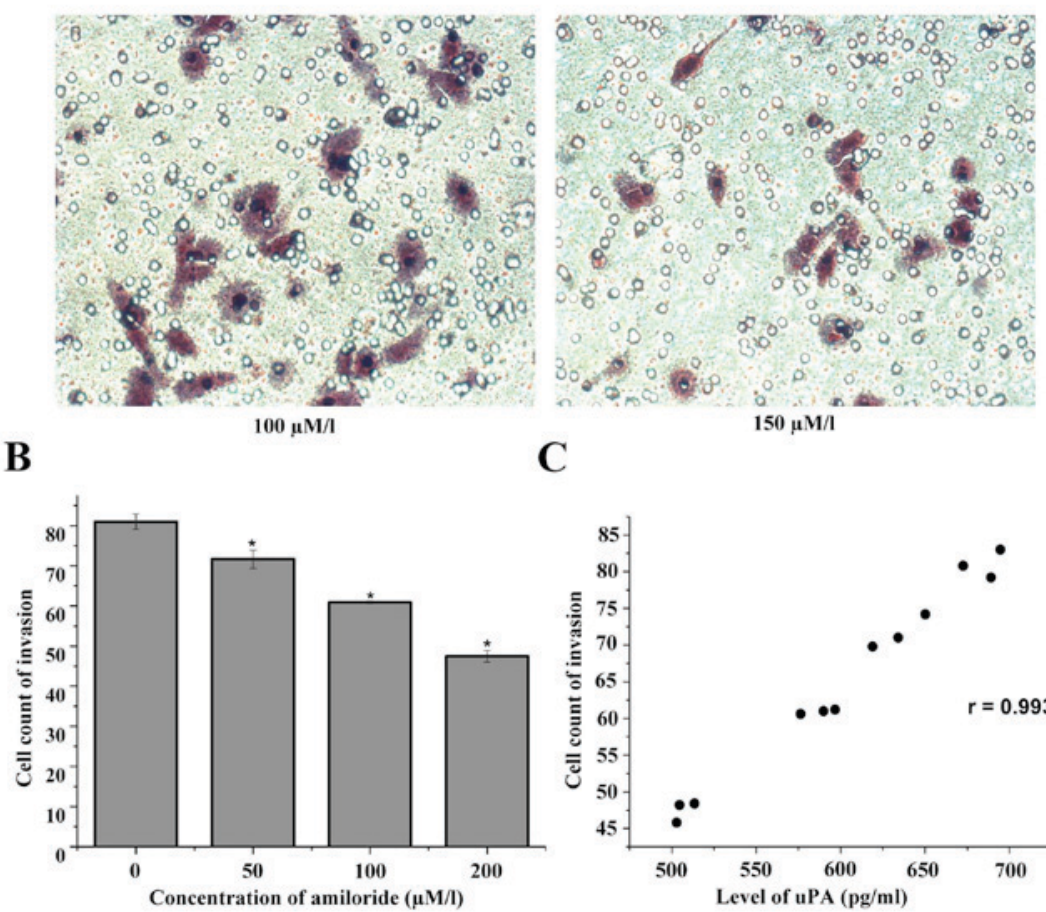

C

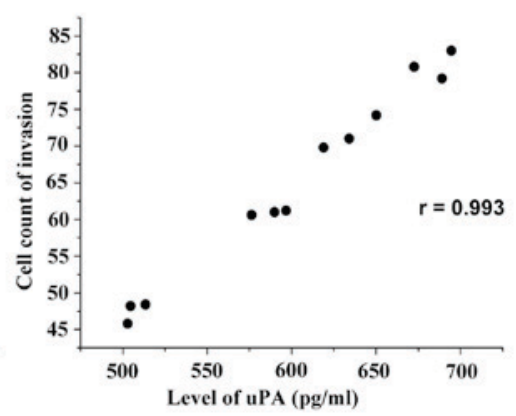

Figure 5. Invasion of HeLa cells following treatment with amiloride (magnification, x100). (A) Following incubation with different concentrations of amiloride $(0,50,100$ or $150 \mu \mathrm{mol} / \mathrm{l})$ for $24 \mathrm{~h}$, the number of HeLa cells which penetrated the Transwell membrane decreased as the concentration increased (B) Quantification of invasion of HeLa cells with different concentrations of amiloride. (C) Correlation between invasion of HeLa cells and different expression levels of uPA. "P<0.01 vs. $0 \mu \mathrm{mol} / 1$. uPA, urokinase plasminogen activator.

the membrane and the concentration of amiloride. Amiloride concentrations of 50,100 and $150 \mu \mathrm{mol} / 1$ decreased the number of membrane-penetrating cells; this result was statistically significant compared with the control group $(\mathrm{F}=226.95$, $\mathrm{P}<0.01$; Fig. $5 \mathrm{~A}$ and $\mathrm{B})$. Additionally, there was a positive correlation between the number of membrane-penetrating cells and the expression level of uPA ( $r=0.993$, P $<0.01$; Fig. 5C).

\section{Discussion}

The invasion and metastasis of malignant tumors, processes primarily regulated by the expression of proteolytic enzymes, is one of the principal causes of treatment failure and mortality in patients diagnosed with cancer. Studies have reported that tumor cell infiltration and metastatic capacity are closely associated with the degree of protease production (18). Tumor cells produce a large number of proteolytic enzyme degradation matrices to facilitate the migration of tumor cells (19). In malignant tumor tissues and cells, there are four principal types of proteolytic enzyme: Serine proteases, cysteine proteases, aspartic acid proteases and MMPs. uPA is an important type of serine protease that is able to stimulate the production of plasmin and plasmin-dependent MMPs (20). MMP-2 has been observed to be highly expressed in various solid tumors, including those in cervical cancer, and is associated with tumorigenesis and prognosis (21-23). Matriptase is a novel serine protease and the upstream regulator of the uPA system (21). It was isolated from the human breast cancer cell line T-47D and milk by Lin et al (24) and is briefly activated in normal cells under specific controllable conditions, although it is consistently activated in cancer cells. UPA, MMP-2, and matriptase have been demonstrated to be overexpressed in cervical cancer cells, while the same phenomenon was not observed in normal cervical cells $(7,8,20,25)$.

Tumor treatment has been advanced by the study of the mechanism of action of uPA series factors. Considering that the modulation of uPA was predicted to regulate tumor invasion and metastasis $(26,27)$, further studies were performed. Following this, the regulation of uPA transcription by amiloride was revealed in numerous studies $(28,29)$. Klinghofer et al $(30)$ 
reported the inhibitory effects of amiloride, B428 and other amidine-based urokinases on the human uPA gene, and that the murine uPA gene was unable to be inhibited. While certain studies have supported the role of the balance of calcium and other ions as an underlying mechanism for the anticancer properties of amiloride, it is clear that a number of the anticancer effects may arise either independently or synergistically via inhibition of uPA $(31,32)$. In the present study, an experiment was performed to demonstrate the effects of different concentrations of the uPA synthetic inhibitor amiloride on a human cervical cancer cell line (HeLa) in vitro. The results demonstrated that amiloride significantly inhibited the mRNA expression level of UPA in HeLa cells in a concentration- and time-dependent manner, whereas the mRNA expression level of UPA reached a plateau when the concentration of amiloride reached $150 \mu \mathrm{mol} / 1$. Increasing drug concentrations were unable to inhibit the mRNA expression of uPA, which may be associated with the saturation effect of drugs on the uPA system. It was additionally demonstrated that the exposure of HeLa cells to amiloride resulted in a significant decrease in the mRNA expression level of MMP-2 following the period of decline in the mRNA expression level of uPA. The possible reason is that the mRNA expression level of uPA may be inhibited by amiloride, followed by inhibition of plasmin activation, leading to a decrease in MMP-2 activation. In the quantitative ELISA, as hypothesized, the levels of uPA and MMP-2 were demonstrated to be downregulated with the increase in concentration of amiloride and treatment duration. The results of the present study additionally demonstrated that there was no significant inhibitory effect of amiloride on the mRNA expression levels of matriptase and uPAR.

The cellular scratch assay was performed to investigate the migratory ability of HeLa cells. The results demonstrated a concentration-dependent effect, whereby amiloride significantly suppressed the migration of HeLa cells; the migration distance of the cells was significantly reduced and wound healing time was prolonged. There was a negative correlation between the concentration of amiloride and the protein expression level of UPA in HeLa cells. Therefore, amiloride was able to downregulate the mRNA expression of uPA in HeLa cells, and suppress the migration of human cervical cancer cells, leading to inhibition of tumor infiltration and growth towards the surrounding tissue.

The Transwell chamber assay was performed to investigate the alteration in invasiveness of HeLa cells following culturing with amiloride. The results suggested that amiloride had anti-invasive effects on HeLa cells in a concentration-dependent manner, which are negatively correlated with the mRNA expression level of uPA in those cells. Therefore, the present study confirmed that amiloride was able to downregulate the mRNA expression of UPA in HeLa cells and suppress the invasion and metastasis of human cervical cancer cells in a concentration-dependent manner.

In conclusion, uPA may be associated with cervical cancer invasion and metastasis-associated genes. The present study partly revealed the association between the uPA system and the behavior of human cervical cancer cells by examining the association between amiloride and mRNA expression levels of matriptase, uPA, uPAR and MMP-2, in addition to the effect of amiloride on the migration and invasion of HeLa cells. The results of the present study further confirmed that amiloride, a type of synthetic uPA inhibitor, may serve a role in the inhibition of tumor invasion by suppressing the mRNA expression level of uPA, and its antitumor role in cervical cancer merits investigation in further studies.

\section{Acknowledgements}

The present study was supported in part by grant no. 2009CXB-33 from the Medical Foundation for Innovation of Fujian Province of China, and grant no. 2007 (170) from the Advanced Program of National Ministry of Personnel for the Returned Overseas Chinese Scholars. The funders had no role in study design, data collection, data analysis, data interpretation or writing of this study. The authors had full access to the data and were responsible for the final decision to submit.

\section{References}

1. de Sanjosé S, Diaz M, Castellsagué X, Clifford G, Bruni L, Muñoz N and Bosch FX: Worldwide prevalence and genotype distribution of cervical human papillomavirus DNA in women with normal cytology: A meta-analysis. Lancet Infect Dis 7: 453-459, 2007.

2. Ferlay J, Shin HR, Bray F, Forman D, Mathers C and Parkin DM: Estimates of worldwide burden of cancer in 2008: GLOBOCAN, 2008. Int J Cancer 127: 2893-2917, 2010.

3. Sahasrabuddhe VV, Parham GP, Mwanahamuntu MH and Vermund SH: Cervical cancer prevention in low- and middle-income countries: Feasible, affordable, essential. Cancer Prev Res (Phila) 5: 11-17, 2011.

4. Hildenbrand R, Allgayer H, Marx A and Stroebel P: Modulators of the urokinase-type plasminogen activation system for cancer. Expert Opin Invest Drugs 19: 641-652, 2010.

5. Blasi F and Sidenius N: The urokinase receptor: Focused cell surface proteolysis, cell adhesion and signaling. FEBS Lett 584: 1923-1930, 2010.

6. Mekkawy AH, Morris DL and Pourgholami MH: Urokinase plasminogen activator system as a potential target for cancer therapy. Future Oncol 5: 1487-1499, 2009.

7. Daneri-Navarro A, Macias-Lopez G, Oceguera-Villanueva A, Del Toro-Arreola S, Bravo-cuellar A, Perez-montfort R and Orbach-arbouys S: Urokinase-type plasminogen activator and plasminogen activator inhibitors (PAI-1 and PAI-2) in extracts of invasive cervical carcinoma and precursor lesions. Eur J Cancer 34: 566-569, 1998.

8. Santin AD, Cane' S, Bellone S, Bignotti E, Palmieri M, De Las Casas LE, Anfossi S, Roman JJ, O'Brien T and Pecorelli S: The novel serine protease tumor-associated differentially expressed gene-15 (matriptase/MT-SP1) is highly overexpressed in cervical carcinoma. Cancer 98: 1898-1904, 2003.

9. Watanabe $\mathrm{H}$ : Extracellular matrix-regulation of cancer invasion and metastasis. Gan To Kagaku Ryoho 37: 2058-2061, 2010.

10. Webb SL, Sanders AJ, Mason MD and Jiang WG: Type II transmembrane serine protease (TTSP) deregulation in cancer. Front Biosci 16: 539-552, 2011.

11. Zitka O, Kukacka J, Krizkova S, Huska D, Adam V, Masarik M, Prusa R and Kizek R: Matrix metalloproteinases. Curr Med Chem 17: 3751-3768, 2010.

12. List K: Matriptase: A culprit in cancer? Future Oncol 5: 97-104, 2009.

13. Jankun J and Skrzypczakjankun E: Molecular basis of specific inhibition of urokinase plasminogen activator by amiloride. Cancer Biochem Biophys 17: 109-123, 1999.

14. Vassalli JD and Belin D: Amiloride selectively inhibits the urokinase-type plasminogen activator. FEBS Lett 214: 187-191, 1987.

15. Livak KJ and Schmittgen TD: Analysis of relative gene expression data using real-time quantitative PCR and the 2(-Delta Delta $\mathrm{C}(\mathrm{T}))$ method. Methods 25: 402-408, 2001. 
16. Liu Y, Han Y, Zhang H, Nie L, Jiang Z, Fa P, Gui Y and Cai Z: Synthetic miRNA-Mowers targeting miR-183-96-182 cluster or miR-210 inhibit growth and migration and induce apoptosis in bladder cancer cells. PLoS One 7: e52280, 2012.

17. Qi S, Song Y, Peng Y, Wang H, Long H, Yu X, Li Z, Fang L, Wu A, Luo W, et al: ZEB2 mediates multiple pathways regulating cell proliferation, migration, invasion and apoptosis in glioma. PLoS One 7: e38842, 2012.

18. Mignatti $P$ and Rifkin DB: Biology and biochemistry of proteinases in tumor invasion. Physiol Rev 73: 161-195, 1993.

19. Jones JL and Walker RA: Control of matrix metalloproteinase activity in cancer. J Pathol 183: 377-399, 1997.

20. Lijnen HR: Matrix metalloproteinases and cellular fibrinolytic activity. Biochemistry 67: 92-98, 2002.

21. Overall CM and Kleifeld O: Tumour microenvironment-opinion: Validating matrix metalloproteinases as drug targets and anti-targets for cancer therapy. Nature Rev Cancer 6: 227-239, 2006.

22. Libra M, Scalisi A, Vella N, Clementi S, Sorio R, Stivala F, Spandidos DA and Mazzarino C: Uterine cervical carcinoma: Role of matrix metalloproteinases (Review). Int J Oncol 34: 897-903, 2009.

23. Baltazarrodriguez LM, Anayaventura A, Andradesoto M, Monrroy-Guizar EA, Bautista-Lam JR, Jonguitud-Olguin G, Cepeda-Lopez FR, Centeno-Aguilar VA, GonzalezHernandez NA, Soriano-Hernández AD, et al: Polymorphism in the matrix metalloproteinase-2 gene promoter is associated with cervical neoplasm risk in Mexican women. Biochem Genet 46 : 137-144, 2008

24. Lin CY, Tseng IC, Chou FP, Su SF, Chen YW, Johnson MD and Dickson RB: Zymogen activation, inhibition and ectodomain shedding of matriptase. Front Biosci 13: 621-635, 2008.
25. Lee JW, Song S, Choi JJ, Lee SJ, Kim BG, Park CS, Lee JH, Lin CY, Dickson RB and Bae DS: Increased expression of matriptase is associated with histopathologic grades of cervical neoplasia. Hum Pathol 36: 626-633, 2005.

26. Danø K, Andreasen PA, Grøndahl-Hansen J, Kristensen P, Nielsen LS and Skriver L: Plasminogen activators, tissue degradation and cancer. Adv Cancer Res 44: 139-266, 1985.

27. Saksela O and Rifkin DB: Cell-associated plasminogen activation: regulation and physiological functions. Annu Rev Cell Biol 4: 93-126, 1988.

28. Wang Y, Jones CJ and Dang J: Human urokinase receptor expression is inhibited by amiloride and induced by tumor necrosis factor and phorbol ester in colon cancer cells. FEBS Lett 353: 138-142, 1994.

29. Wang Y, Dang J, Liang X and Doe WF: Amiloride modulates urokinase gene expression at both transcription and post-transcription levels in human colon cancer cells. Clin Exp Metastasis 13: 196-202, 1995.

30. Klinghofer V, Stewart K, Mcgonigal T, Smith R, Sarthy A, Nienaber V, Butler C, Dorwin S, Richardson P, Weitzberg M, et al: Species specificity of amidine-based urokinase inhibitors. Biochemistry 40: 9125-9131, 2001.

31. Park KS, Poburko D, Wollheim CB and Demaurex N: Amiloride derivatives induce apoptosis by depleting $\mathrm{ER} \mathrm{Ca}(2+)$ stores in vascular endothelial cells. Br J Pharmacol 156: 1296-1304, 2009.

32. Matthews H, Ranson M and Kelso MJ: Anti-tumour/metastasis effects of the potassium-sparing diuretic amiloride: An orally active anti-cancer drug waiting for its call-of-duty? Int J Cancer 129: 2051-2061, 2011

cc)(ㅇ) This work is licensed under a Creative Commons (c) ${ }_{\mathrm{EY}} \mathrm{NO} \mathrm{NO}$ Attribution-NonCommercial-NoDerivatives 4.0 International (CC BY-NC-ND 4.0) License. 